\title{
From Basic Chronic Wounds To Mortal Endings: Squamous Cell Carcinoma Arising from Hidradenitis Suppurativa and Pilonidal Sinus
}

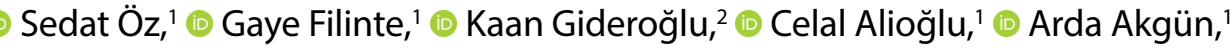 \\ (1) Sultan Yalçın, ${ }^{1}$ (ㄷ) Kübra Kalafatlar, ${ }^{1}$ (1) Tunç Tunçbilek, ${ }^{1}$ (1) Cem Sınacı,

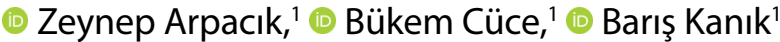

\begin{abstract}
'Department of Plastic and Reconstructive Surgery, University of Health Sciences Kartal Dr. Lütfi Kırdar Training and Research Hospital, İstanbul, Turkey ${ }^{2}$ Department of Plastic and Reconstructive Surgery, University of Health Sciences, Fatih Sultan Mehmet Training and Research Hospital, İstanbul, Turkey

Submitted: 15.02.2018 Accepted: 07.09.2018

Correspondence: Sedat Öz SBÜ Kartal Dr. Lütfi Kırdar Eğitim ve Araștırma Hastanesi, Plastik ve Rekonstrüktif Cerrahi Kliniği, İstanbul, Turkey

E-mail: oz.sedat@hotmail.com

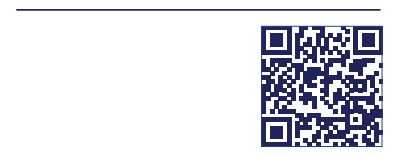

Keywords: Hidradenitis suppurativa; Marjolin's ulcer; pilonidal sinus; squamous cell carcinoma.
\end{abstract}

\begin{abstract}
Marjolin's ulcer is an aggressive ulcerating malignancy that arises in a chronic wound and most often takes the form of squamous cell carcinoma (SCC). It often occurs in old burn scars, but it may also develop in post-traumatic lesions or chronic wounds. The prognosis is often poor as a result of delayed diagnosis. Presently described are cases in which chronic hidradenitis suppurativa and pilonidal sinus developed into SCC.
\end{abstract}

\section{INTRODUCTION}

Cutaneous squamous cell carcinoma (SCC) is a malignant, invasive, and metastatic skin tumor originating from epidermal keratinocyte cells, and constitutes approximately $20 \%$ to $30 \%$ of malignant skin tumors. ${ }^{[1]}$ A number of factors may play a role in the etiology of SCC. The most frequently seen are environmental carcinogens such as arsenic, ultraviolet light exposure, fair skin, DNA repair defects, human papilloma virus infection, immunosuppression, ionizing radiation exposure, and chronic ulcers. ${ }^{[2]}$ Tumors may develop in healthy skin, or they may originate from precursor lesions in cases of Bowen's disease, actinic cheilitis, Marjolin's ulcer, leukoplakia, and diseases. ${ }^{[3]}$ Ulcerative lesions in chronic scar tissue were first described by Jean Nicholas Marjolin in 1828, and malignant degeneration was demonstrated by Daccosta in 1903. ${ }^{[4]}$ Marjolin's ulcer is a rare lesion frequently originating from aggressive, 
chronic wounds and old scars that then become cancerous growths. ${ }^{[5]}$ Cases of Marjolin's ulcer have been reported most often in chronic burns (76\%), and less frequently $(2 \%)$, venous ulcers $(6.3 \%)$, and traumatic injuries $(8.1 \%)$. ${ }^{[6]}$ The formation typically occurs slowly, but the pathogenesis is not fully understood. ${ }^{[7]}$ Therefore, it is important to monitor chronic wounds carefully and diagnostic biopsies should be performed if there is any suspicion.

\section{CASE REPORT}

Case I- A 54-year-old male patient presented at an outpatient clinic to inquire about an area of scarring with an occasional malodorous discharge located in the sacral region that had been present for approximately 30 years. The patient did not have any additional illnesses; however, his history did include 35 pack-years of smoking. The clinical findings were determined to be compatible with hidradenitis suppurativa and medical treatment was planned. A malignant transformation was suspected and a biopsy was performed. The reported result was hyperkeratosis. The patient was reassessed a year later upon worsening of his complaints of discharge and wound dehiscence, and the result of an incisional biopsy was a preliminary diagnosis of SCC and verrucous carcinoma. Magnetic resonance imaging and ultrasound results of the sacrum and regional lymph nodes did not suggest metastasis. A broad area was excised and the material was evaluated by pathologists using frozen section analysis. The result confirmed the diagnosis of SCC. The wound site was repaired with a partial thickness skin graft. No evidence of a recurrent lesion was detected during a year of follow-up.

Case 2- A 52-year-old male patient presented at the general surgery clinic with painful and swollen lesions in the gluteal region. The clinical findings were consistent with pilonidal sinus and medical treatment was initiated; however, an optimal response was not obtained. Surgery was performed, and the pathology report for the excised material indicated the presence of pilonidal sinus. Followup for the wound and tissue defect was performed at the polyclinic, and following periodic episodes of exacerbation over the course of a year, a diagnostic biopsy was planned. Debridement was performed and the pathology report of the material indicated a preliminary diagnosis of well-differentiated SCC in the fistula tract. Advanced imaging techniques were used during the follow-up period, and subsequently, extensive excision and reconstruction were planned. The pathology report of the specimen obtained during surgery indicated a finding of well-differentiated SCC that had developed in a pilonidal cyst. Reconstruction was performed using a local flap. No evidence of a recurrent lesion was detected during 2 years of follow-up.

\section{DISCUSSION}

Marjolin's ulcer frequently develops in burn wounds, but it can also originate in chronic lesions such as pressure sores, venous ulcers, or perianal sites of chronic inflammation or hydronephrosis suppurativa that heal with a scar. The most important clinical signs that may suggest the development of Marjolin's ulcer are rolled wound edges, irregular borders, skin infiltration, and increased pain at the site. Most commonly, it will become well differentiated SCC, but it can also develop into other malignant lesions, such as BCC and sarcomas. ${ }^{[8]}$ The average length of time for malignant transformation is 28.7 years. ${ }^{[9]}$ Clinical suspicion of Marjolin's ulcer in the presence of risk factors is very important for early diagnosis.

In cases of small, noninvasive, well-differentiated tumors, surgical excision and grafting are sufficient. In moderately or poorly differentiated lesions or well- differentiated large and invasive ulcers, broad surgical excision is recommended, and if it is localized on an extremity, amputation may be required. ${ }^{[10]}$ Since SCC is the most common lesion to develop after Marjolin's ulcer, the lymph nodes and distant organs should be assessed for metastasis.

The metastasis rate is approximately $15 \%$ and most commonly occurs in the regional lymph nodes. Distant organ metastasis may also occur in the lungs, brain, or spleen. In cases of lymph node or visceral metastasis, the survival

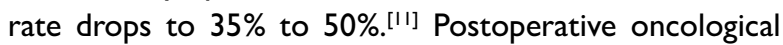
treatment may be necessary. The prognosis of Marjolin's ulcers varies depending on local spread, location, histological type of the ulcer, immune status of the patient, and most importantly, lymph node metastasis. ${ }^{[12]}$ When SCC develops from Marjolin's ulcer, the prognosis is poorer and the rate of metastasis increases. ${ }^{[13]}$ The average 5 -year survival rate is $30 \%{ }^{[14]}$ For early prevention of this condition, diagnostic biopsies are recommended as part of wound care and repeated at frequent intervals and from multiple sites as necessary. ${ }^{[15]}$

\section{CONCLUSION}

As demonstrated in this study, awareness of the potential for malignant transformation in a wound over time is important, even though the wound may appear to be no more than a simple lesion. Marjolin's ulcer is likely to develop into SCC, and the prognosis can be poor. Surgeons and practitioners in other branches frequently encounter chronic wounds and must manage wound care and follow-up. Clinicians should maintain suspicion of a malignant formation in chronic wounds and work with plastic and reconstructive surgery specialists in order to achieve healthy outcomes.

\section{Informed Consent}

Written informed consent was obtained from the patients 
for the publication of the case reports and the accompanying images.

Peer-review

Internally peer-re viewed.

Authorship Contributions

Concept: S.Ö., G.F;; Design: S.Ö., A.A.; Data collection \&/or processing: S.Ö., K.G., C.A., K.K., T.T., Z.Y., B.C., B.K.; Analysis and/or interpretation: S.Y., C.B.S.; Literature search: S.Ö.; Writing: S.Ö.; Critical review: G.F.

Conflict of Interest

None declared.

\section{REFERENCES}

1. Fishman JR, Parker MG. Malignancy and chronic wounds: Marjolin's ulcer. J Burn Care Rehabil 1991;12:218-23. [CrossRef]

2. Kundakçı N, Erdem C. Lepra ve diğer mikobakteriyel deri infeksiyonları. Dermatoloji'de. In: Tüzün Y, Gürer MA, Serdaroğlu S, Oğuz O, Aksungur, editors. 3rd. İstanbul: Nobel Tip Kitabevi; 2008. p. 433-58.

3. Hensel KS, Ono CM, Doukas WC. Squamous cell carcinoma in chronic ulcerative lesions: a case report and literature review. Am J Orthop 1999;28:253-6.

4. Da Costa JC. III. Carcinomatous Changes in an Area of Chronic Ulceration, or Marjolin's Ulcer. Ann Surg 1903;37:496-502.

5. Daya M, Balakrishan T. Advanced Marjolin's ulcer of the scalp in a 13-year-old boy treated by excision and free tissue transfer: Case report and review of literature. Indian J Plast Surg 2009;42:106-11.

6. Agale SV, Kulkarni DR, Valand AG, Zode RR, Grover S. Marjolin's ulcer-a diagnostic dilemma. J Assoc Physicians India 2009;57:593-4.

7. Dupree MT, Boyer JD, Cobb MW. Marjolin's ulcer arising in a burn scar. Cutis 1998;62:49-51.

8. Calikapan GT, Akan M, Karaca M, Aköz T. Marjolin ulcer of the scalp: intruder of a burn scar. J Craniofac Surg 2008;19:1020-5.

9. Kerr-Valentic MA, Samimi K, Rohlen BH, Agarwal JP, Rockwell WB. Marjolin's ulcer: modern analysis of an ancient problem. Plast Reconstr Surg 2009;123:184-91. [CrossRef]

10. Samira Y, Sérgio H, Michalany NS, de Almeida FA, Jane T. Squamous cell carcinoma in chronic ulcer in lepromatous leprosy. Dermatol Surg 2009;35:2025-30. [CrossRef]

11. Karadağ AS, Akdeniz N, Çalka Ö, Çeçen İ, Bayram İ, Ceylan F. Plantar Ülser Zemininde Skuamöz Hücreli Karsinom Gelişen Bir Lepra Olgusu. Dermatoz 2010;1:185-7.

12. Rook's textbook of dermatology. D. A. Burns, S. M. Breathnach, Neil Cox, Christopher E. Griffiths, editors. 7th. Oxford: Blackwell Publishers; 2004. p. 4568.

13. Huang CY, Feng CH, Hsiao YC, Chuang SS, Yang JY. Burn scar carcinoma. J Dermatolog Treat 2010;21:350-6. [CrossRef]

14. Esther RJ, Lamps L, Schwartz HS. Marjolin ulcers: secondary carcinomas in chronic wounds. J South Orthop Assoc 1999;8:181-7.

15. Sabin SR, Goldstein G, Rosenthal HG, Haynes KK. Aggressive squamous cell carcinoma originating as a Marjolin's ulcer. Dermatol Surg 2004;30:229-30. [CrossRef]

\section{Basit Kronik Yaralardan Mortal Sonuçlara; Hidradenitis Suppurativa ve Pilonidal Sinüs Zemininde Gelişen Skuamöz Hücreli Karsinom}

Marjolin ülseri (MU) yanık ve kronik yara zemininde gelişen, agresif seyreden ve skuamöz hücreli karsinom (SHK) dönüşümü gösteren malign cilt tümörüdür. Daha sıklıkla uzun dönem yanık zemininde görülmekle birlikte travma sonrası ya da kronik diğer yaralarda da karşımıza çıkmaktadır. Genellikle ön tanılarda düşünülmeyip tanısı geç konmakta ve bu yüzden prognozu kötü seyretmektedir. Bu çalışmada, iki olguda uzun dönem takip edilen hidradenitis suppurativa ve pilonidal sinüs lezyonlarının MU zemininde SHK'ya dönüşümü sunuldu.

Anahtar Sözcükler: Hidradenitis suppurativa; Marjolin ülseri; pilonidal sinüs; skuamöz hücreli karsinom. 